\title{
AC 2008-1457: INCORPORATING A LEARNING COMMUNITY APPROACH TO ENHANCE A FUEL CELL RESEARCH EXPERIENCE FOR UNDERGRADUATES (REU)
}

\section{Cortney Martin, Virginia Polytechnic Institute and State University}

Dr. Cortney V. Martin has worked in information design, pedagogy, and education for over 15 years including serving as the Assistant Director of the Blacksburg Electronic Village and the Broadband Wireless Networking Director for Virginia Tech. She teaches as a part of an innovative interdisciplinary thematic four-course sequence focused on Earth Sustainability and serves as the Research Coordinator for a fuel cell REU program. Her PhD is in Industrial Engineering (human factors) from Virginia Tech.

\section{Brandy Bratton, Virginia Polytechnic Institute and State University}

Brandy B. Barrow is a graduate student in the Department of Educational Research and Evaluation. She has been on the SURP evaluation team for the past three years.

\section{David Dillard, Virginia Polytechnic Institute and State University}

Dr. David A. Dillard is the Adhesive and Sealant Science Professor in the Engineering Science and Mechanics Department at Virginia Polytechnic Institute and State University. His research is focused in the area of time dependent properties and fracture of polymeric materials, most recently in fuel cell applications. This interest spawned development of the Materials and Processes for Proton Exchange Membrane Fuel Cells Research Experience for Undergraduates.

\section{Michael Ellis, Virginia Polytechnic Institute and State University}

Dr. Michael W. Ellis is an Associate Professor of Mechanical Engineering at Virginia Tech and co-PI of the Materials and Processes for Proton Exchange Membrane Fuel Cells Research Experience for Undergraduates. He has a $\mathrm{PhD}$ from Georgia Tech.

\section{Maggie Bump, Virginia Polytechnic Institute and State University}

Dr. Maggie B. Bump received her teaching certification in 1996 and her Ph.D. in Synthetic Polymer Chemistry in 2001 from Virginia Tech. She continues her work at Virginia Tech, teaching Organic Chemistry and directing the Summer Undergraduate Research Program (SURP) for the Macromolecules and Interfaces Institute. In her capacity as SURP Director, she has also developed and implemented the Young Scientist Experience for children. 


\title{
Incorporating a Learning Community Approach to Enhance a Fuel Cell Research Experience for Undergraduates (REU)
}

\begin{abstract}
Undergraduate summer research experiences typically involve a mix of solitary research coupled with traditional classroom-based seminars. The short duration of the experience and the often isolated nature of the project can preclude development of the network of personal interactions that characterizes contemporary collaborative research and learning. This paper discusses steps that have been taken to transition the Materials and Processes for Proton Exchange Membrane Fuel Cells Research Experience for Undergraduates to a learning community model. In 2007, a research group facilitator position was added to build rapport among students, encourage dissemination of research through publications and presentations, and to guide their choice and voice in their summer experience. Programmatic changes included weekly brown bag lunches, student-initiated lab tours, peer problem solving and editing, and social events. Exit interview data revealed that this was a positive change resulting in a better sense of community and a more rewarding and successful experience. Future additions to the program will include gathering program input at the start of the summer to shape seminars and workshops, offering training and support to mentors, incorporating a book club element to the brown bag lunches, expanding networking opportunities, and offering additional resources to support the communication goals. Based on our results, other REUs are encouraged to incorporate learning community principles to add value to the experience for their participants.
\end{abstract}

\section{Introduction}

Learning community frameworks are being increasingly utilized in classrooms and residential settings because they are recognized as providing pathways to greater student learning and development - personal, interpersonal, and epistemological ${ }^{1,2}$. There are many contexts for learning communities in both formal and informal educational settings, but the common theme is that the students are actively and collaboratively vested in their own learning, which results in greater student engagement ${ }^{3}$. Learning communities are well-suited to contribute to the training and development of engineers in areas such as teamwork and communication skills, but also in collaborative design, problem solving, ethics, and an understanding of the larger context for their work.

Undergraduate summer research programs have historically been founded on traditional pedagogy: instructor-led seminars and faculty-directed research and problem solving, with the latter often including an experienced graduate student or postdoctoral mentor. The selfcontained nature of summer research projects often contribute to the sense of isolation that does not accurately reflect contemporary research. We propose changing the program paradigm from a traditional faculty-centered approach to a student-centered learning community approach. Empirical studies tell us that learning communities can increase student engagement over traditional didactic models. Students are expected to develop a greater sense of ownership and thus enhanced self-efficacy with regard to their personal research and collaborative abilities. In addition to enabling students to have a rich research experience, the program is also designed to 
further prepare and encourage a more diverse group of students to pursue advanced degrees and careers in engineering and sciences related to alternative energy sources in general and PEM fuel cells in particular. This paper discusses our experiences in moving our Materials and Processes for Proton Exchange Membrane Fuel Cells Research Experience for Undergraduates (Fuel Cell REU) toward a learning community model in 2007 as well as additional changes that are anticipated for 2008.

\section{Summer Undergraduate Research Program}

The 19th Annual National Science Foundation Summer Undergraduate Research Program (SURP) was held at Virginia Tech in Blacksburg, VA from May 21 through August 10, 2007. SURP is an umbrella program that incorporated four related programs in the 2007 offering: Materials and Processes for Proton Exchange Membrane Fuel Cells, Field Responsive Materials, Molecular Interfaces with Life Sciences (MILES), and Macromolecular Science \& Infrastructure Engineering. These SURP programs have been primarily funded through the National Science Foundation; the former two programs are Research Experience for Undergraduates (REU) sites and the latter two programs are Integrative Graduate Education and Research Traineeship (IGERT) programs. A total of twenty-four students were involved in the four groups and the students participated in many of the same traditional activities and seminars. Each student had at least one faculty advisor and one graduate or postdoctoral mentor.

There were several common, traditional elements to the summer program that were shared among all the students. The summer began with a four day short course involving lectures on polymeric materials, fuel cells, lab equipment, and safety procedures to orient the students to the work in which they would be involved. Students had a chance to visit several of the laboratories that house common equipment used by many of the student participants.

Throughout the summer, students worked on a journal style paper to be presented at an end-ofsummer research symposium. To better enable them to be successful, students took part in a weekly communications seminar course. Topics included:

- Communication in research environments

- One minute drills - discussing your research succinctly

- Professional ethics

- Resume writing

- Scientific presentations and Power Point

- Applying to graduate school

- Searching technical literature

- Using bibliographic software

Students had the opportunity to participate in an outreach program, SURP's Young Scientist Experience, a mini-camp for middle school children that was held over three consecutive afternoons in June. The children, with the support of our students, created and staffed a booth to explain technologies to the general public at our summer community festival, Steppin' Out. In this way, hundreds of children and their parents were introduced to polymers and related 
technologies (including fuel cells) and our students gained experience with teaching and public relations.

At the conclusion of the program, SURP participants completed exit surveys and exit interviews to inform future programs. Student participants nominated mentors for awards.

\section{Fuel Cell REU Learning Community}

The nine students in the Fuel Cell REU group had one additional mentor - a research group facilitator tasked with developing a collegial community among its members as well as helping to foster dissemination of research through publications and presentations. The group facilitator had training and experience directing an interdisciplinary classroom learning community and extended the principles through community-building activities and peer teaching, problem solving, and editing. This individual was able to contribute to the program in a number of ways, in part because she was able to take additional time with individual students to assist with personal and professional issues and questions, topics that are often difficult to raise with the faculty advisor. The nine fuel cell participants negotiated their own ways of interacting and supporting one another. There were a number of ways in which this group was unique.

In the first week, the fuel cell group gathered to investigate the relevance of their research in a global context. The group discussed available energy options, pros and cons, and the implications of the dependence on foreign oil. Two videos were shown, Earth's Clean Energy Destiny (2000) and The Hydrogen Age (2005). The history of the fuel cell was explored to lead into the next activity. A hands-on fuel cell laboratory experience enabled the students to more fully engage with and appreciate the processes as they used solar energy to hydrolyze water which then powered small circuits (Figure 1).

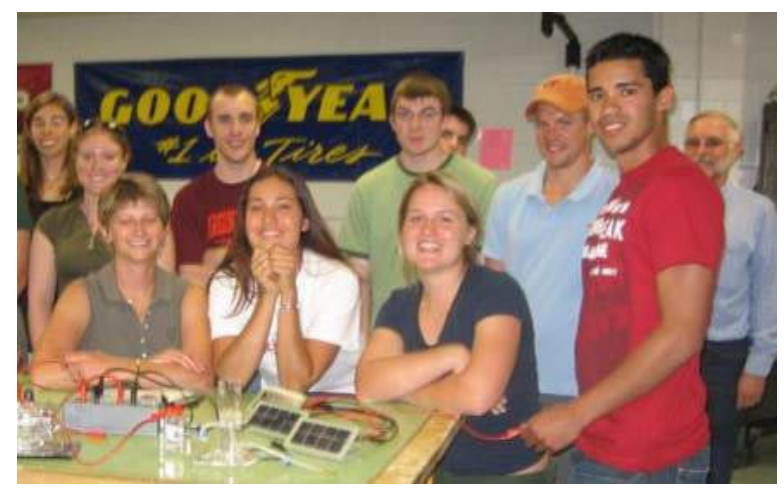

Figure 1. Hands-on learning with fuel cells.

Six fuel cell seminar/discussion programs were offered featuring speakers from outside industry as well as from within the university. The seminars included entrepreneurial, scientific, and global energy perspectives to broaden their understanding of contemporary fuel cell and energy research needs.

Three students volunteered with the Young Scientist Experience, initiated by the Field Responsive Materials REU site, to team with a group of middle school children to teach them the fundamentals of fuel cell technology using model fuel cell cars (Figure 2). The team, in turn, 
taught the public as described in the previous section. By seeing children and adults respond so enthusiastically to the technology, our students were further energized, and that enthusiasm carried forward into their own research projects.

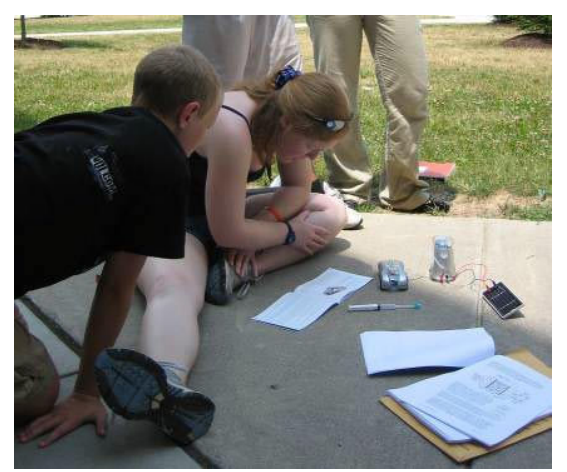

Figure 2. Young scientist participant working with REU undergraduate student.

Weekly brown bag lunches were initiated in 2007 and proved central to building community. These provided a time to touch base, group problem solve, and to direct activities that were student-initiated. At the first lunch, students responded to an open-ended survey, asking what they were most excited about, most concerned about, and what they would like to do as a group. A discussion of collegiality and collaborative approaches to research ensued. From that, students elected to take turns hosting lab tours and informal discussions of their projects. This gave students a better idea of the range and breadth of related research being conducted within the REU site program. During the tours, students spontaneously questioned one another and contributed to research approaches, helped solve problems, and suggested other applications for the study.

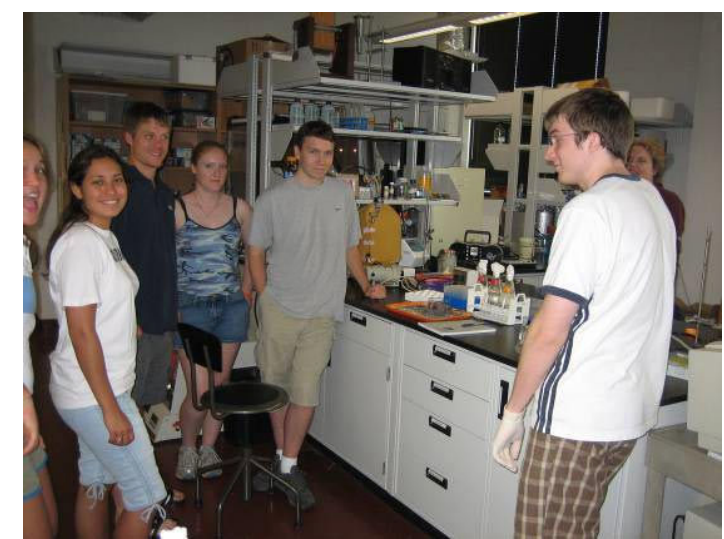

Figure 3. Students participating in a lab tour.

Throughout the phased, summer-long paper-writing process, the students posted drafts and paired off to peer review one another's papers. More difficult issues and questions were brought to the lunches for discussion with peers and the research group facilitator. Students had varying levels of experience with technical writing and were able to help one another which reinforced 
their own understanding. The facilitator met with student/graduate mentor pairs at least once to discuss project and paper progress.

Students suggested a number of extracurricular activities such as field trips to visit local labs and related businesses. Social activities included weekend trips, movie nights, hikes, and pot luck dinners. The learning community was supported with the tools of Blackboard as well as Facebook.

\section{Results from 2007}

The learning-community approach, although not fully implemented, showed evidence of creating a more satisfying summer research experience as reflected by exit interview comments:

Yeah, we had [the facilitator] and she was great-very interested in our work and she kept us motivated. I had good networking opportunities with other SURP students during our brown bag lunches. I really enjoyed our brown bag lunches. Hearing what other students were working on helped me feel like I was staying on track.

[The facilitator] was awesome. She really cared about us and I think our group got along better and became good friends because she got us to work together. Everyone else seemed to be doing their own thing but our group actually hung out after work.

The first week's energy discussion and hands-on fuel lab may have given students a leg-up on understanding how their project related to actual energy needs, as reflected by one participant, "I have had a chance to look at research and how it fits into the real world." That is a key discovery as the US needs researchers who can identify and address meaningful problems in a geopolitical as well as scientific and engineering context.

Peer review and editing offered advantages over the traditional teacher-student feedback mechanism and offered a more realistic model of how writing is done. One student reflects:

[A challenge I had to overcome was] learning how to write an article. I had issues with the format and my writing style is different from the technical writing style. But I learned a lot just by our seminar and reading other people's work and seeing what types of articles get accepted in the top journals.

The sample size (number of participants) was not large enough to provide sufficient power to determine if the learning community approach impacted goals or satisfaction as measured by the five-point exit survey scale. However, anecdotally, it does seem to be moving outcomes in the right direction. In fact, students were forthcoming about other areas of the program that followed more traditional models of pedagogy and could benefit from more active learning:

I really wish some of the communications courses could have been more interactive.

Oh, the short courses did not apply to my project. Those should be optional for next year. 
I do not like presentations that last for more than an 30 minutes. I just get bored and distracted. Some of the presentations seemed to go on forever. I really liked the fuel cell presentations. They were interesting but they were too long.

These serve as reminders that particularly in a summer program that functions more as an internship, it is important that participants have some choice and input into how they spend their time. Students selected for the program come with strong credentials that are clearly backed with good work ethics. However, activities need to be framed - the importance, relevance, and application must be expressly communicated:

I think the communications courses could be improved. There should be an application component to every single seminar. People need to know WHY this is important so that students will pay attention.

An overt, transparent pedagogy is a hallmark of learner-centered instruction and of learning communities. Participants should understand why they are asked to direct their energies in a particular way.

The community lunches and collaborative student activities provided a good start in the transition to a learning community model. More activities can be adapted as described in the following section.

\section{Plans for 2008}

For the 2008 Fuel Cell REU program, we plan to implement several changes and additional programs to continue to build collegiality and to attract students to research in alternative energy sources. The brown bag lunches will continue in some form agreed upon by the students. This year, we will add a "book club" element. We plan to provide the book, Hydrogen - Hot Stuff Cool Science: Discover the Future of Energy ${ }^{4}$ by Rex Ewing. We'll read and discuss the role of fuel cells in the future through this fun and imaginative yet scientifically grounded book that paints a picture of fuel cells in the future. This should provide a common and ongoing framework to link our projects and researchers. In addition, students will have the option of participating in movie nights on campus, with student-selected movies for fun as well as movies related to energy.

Additional opportunities to meet and work as a group will be made available as desired. Possibilities include: field trips to area businesses, social outings, hikes, and potlucks. Students have also been invited to participate in the $\mathrm{C}-\mathrm{Tech}^{2}$ summer program for high-school girls. Because slots for participation in the Young Scientist Experience camp are limited, this will allow more students to have the opportunity for outreach.

One of the bigger changes anticipated is that we plan to offer a mentor training session at the start of the summer to inform graduate mentors about the goals of the REU program and give them the tools to be effective, successful mentors. We found that although the mentors have well-established technical tools and skills, there were other areas in which they could gain skills, such as knowing guiding rather than dictating, providing constructive feedback, and working 
with personal differences. And mentors need support as well, and in the spirit of shared learning, newer mentors can learn from experienced mentors at the training session. It is important that mentors appreciate what they have to gain from participation and how the experience can help them as they move into academic or laboratory positions overseeing others.

Lastly, in response to many comments, we will solicit input on the seminars and short-course topics and adapt the sessions in response to these stated needs. Sessions will be framed so students understand the relevance and importance of the topic, and time will be spent more in discussion and hands-on activities than in traditional lectures.

\section{Conclusions}

The purpose of this REU site is to nurture a diverse group of talented undergraduate students to develop an appreciation for research and scholarship, a broader base of knowledge, a better understanding of the research process, and a desire to contribute to advances in science and engineering through graduate research and professional careers. However, we also want participants to experience the joy of research as they tread in unknown territories, overcome difficulties, and ultimately uncover new knowledge with the help of colleagues and mentors. We want them to experience the excitement of shedding light on a problem for a colleague. They need to recognize that we have created our world's energy problems as a group, and only as a group can they be addressed. After a lifetime of being told what to learn and how to learn, they must find their voice and ultimately be self-directed in their journey. And we need to provide them the opportunity to use their voice and practice self-direction. That is why a learning community approach to a summer research experience is important for nurturing future researchers.

Other REU sites are encouraged to work to build community among their participants by focusing on five main areas. First, create community through negotiated activities such as brown bag lunches, social events, and lab tours. Secondly, emphasize personal responsibility by offering guided choice and some self-selection for participation in hand-on, active learning seminars and events. Third, encourage processes for peer problem-solving and peer review. Fourth, provide opportunities for undergraduate researchers to serve as teachers and mentors through outreach experiences such as with K-12 students and the community. And lastly, provide training to graduate mentors to foster their development as mentors which will result in better support for the undergraduate researchers.

\section{Acknowledgements}

The Materials and Processes for Proton Exchange Membrane Fuel Cell Research Experience for Undergraduates is supported by the Department of Defense in partnership with National Science Foundation Grant No. EEC-0552738. 


\section{References}

1. Baxter Magolda, M. B., \& King, P. M. (2004). Learning partnerships : theory and models of practice to educate for self-authorship. Sterling, Va.: Stylus.

2. Lenning, O. T., \& Ebbers, L. H. (1999). The Powerful Potential of Learning Communities: Improving Education for the Future. ASHE-ERIC Higher Education Report Volume 26, No. 6. Washington, D.C.: The George Washington University, Graduate School of Education and Human Development.

3. Zhao, C.-M., \& Kuh, G. D. (2004). Adding Value: Learning Communities and Student Engagement. Research in Higher Education, 45(2), 115.

4. Ewing, R. A. (2007). Hydrogen - Hot Stuff Cool Science 2nd Edition: Discover the Future of Energy. Masonville, CO: PixyJack Press. 